\title{
VERB PLACEMENT IN EMBEDDED SENTENCES IN FAROESE
}

\author{
MAUD WESTENDORP \\ UiT The Arctic University of Norway
}

\section{ABSTRACT}

In this article, I present data from the Nordic Word order Database (NWD) on word order in Faroese embedded clauses. I discuss the methods used in the data elicitation, data analysis, and present a first overview of the patterns in the dataset. The NWD contains a total of 4,752 embedded clauses elicited from 33 native Faroese speakers, focussing on embedded wh-questions, and the placement of the finite verb with respect to adverbs in different types of complements. The results from the Faroese fieldwork largely confirm the word order patterns discussed in the literature. There is very little variation in the word order of embeddded wh-questions in the NWDdata. Verb > Adverb order is most common in declarative bridge-verb complements, whereas non-bridge, and wh-complements disfavour this order.

\section{[1] INTRODUCTION}

This article reports on fieldwork that took place in August 2018, where a total of 33 native speakers of Faroese participated in a spoken elicited production task. During this fieldwork, sessions were recorded in three locations in the Faroe Islands: Tórshavn, Fuglafjørður and Klaksvík (see Figure 1). The fieldwork was part of a research project developing the Nordic Word order Database (NWD). The design for the experiments in the research project is described in detail in an overview article about NWD (Lundquist et al. 2019). In the present article, we cover only macro-experiment 2 (idem: 14-16), which examines word order in embedded sentences. ${ }^{1}$ For Faroese, the placement of finite embedded verbs with respect to adverbs is particularily interesting. A total of 4,752 sentences from 33 native speakers participating in this experiment were recorded during the fieldwork, and all these sentences are available in the online Nordic Word order Database.

[1] See Lundquist (2020) for macro-experiment 1 targetting placement of arguments and adverbs/particles in Faroese. 
The structure of the article is as follows. In Section 2, I present the syntactic properties of Faroese relevant for this experiment. Section 3 describes the design and material used in the experiment, Section 4 presents the experimental procedure, and Section 5 gives a short overview of the participants. A brief look at the results, based on the data available in the online database, is provided in Section 6. Section 7 concludes the paper.

\section{[2] BACKGROUND}

\section{[2.1] Faroese}

There are an estimated number of $75-$ 80,000 speakers of Faroese, of which approximately 50,000 live in the Faroe Islands. There is furthermore a large number of Faroese speakers in Denmark, and

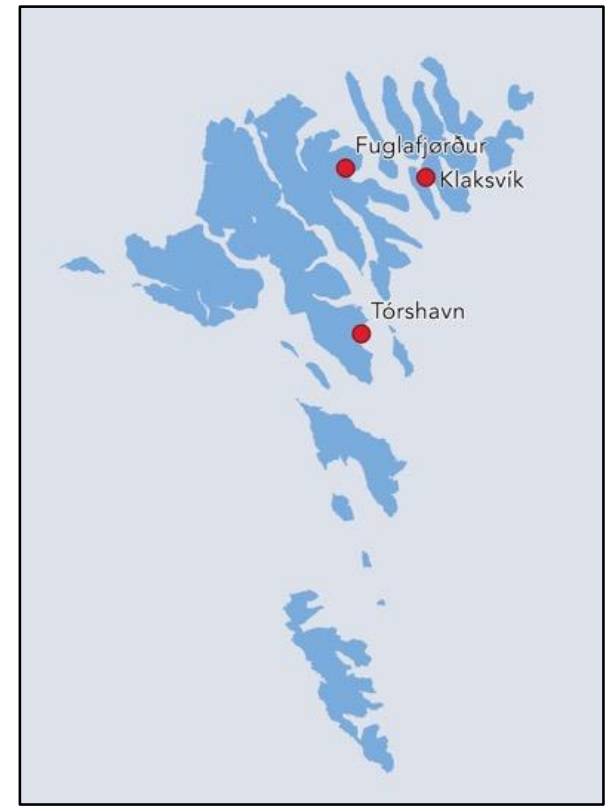

FIGURE 1: Overview of fieldwork locations in the Faroe Islands. a smaller portion living in Iceland (Føroya landsstýri 2019). Faroese speakers learn Danish in school, and there is significant exposure to Danish via media and other popular culture. All speakers are proficient Faroese-Danish bilinguals. In addition, most younger speakers are proficient in English as well (Petersen 2010). Faroese shares many syntactic traits with the other North Germanic languages, and its syntax is fairly well-studied. Nonetheless, there are still many phenomena that are not well-documented, and direct comparisons between Faroese and the other North Germanic languages are not often made.

The current report discusses data on Faroese embedded verb movement. The frequencies of the different structural realizations reported in this article will be directly comparable to frequencies from the other North Germanic languages, as can be obtained directly from the NWD web interface, or from the other articles in this volume.

\section{[2.2] Embedded verb placement}

Faroese is a verb second (V2) language that seems to have developed into an asymmetric V2 language, much like the Mainland North Germanic languages (MNG). V2 is obligatory in Faroese main clauses (see (1) below), and optional in many, but not all, subordinate contexts, similar to MNG (Vikner 1995). This is 
exemplified in (2), adapted from Thráinsson et al. (2004:242-244). In the complement of the bridge-verb halda 'think' (2a), the finite embedded verb can precede or follow the adverb, but in embedded questions (2b) the Verb > Adverb order is unnatural for "many (probably most) speakers of modern Faroese" (idem: 244).

(1) Jógvan hevur aldri lisið bókina. Jógvan has never read book.DEF 'Jógvan has never read the book.'

(2) a. Eg haldi, at Jógvan \{hevur\} aldri \{hevur\} lisið bókina. I believe cOMP Jógvan has never has read book.DEF 'I think Jógvan has never read the book.'

b. Hon spurdi, hvør '\{hevur\} aldri \{hevur\} lisið bókina. she asked who had never had read book.DEF 'She asked who has never read the book.'

The status of embedded Verb $>$ Adverb order in Faroese is still under discussion (see e.g., Thráinsson 2003; Heycock et al. 2010, 2012). There seems to be a consensus in the literature that the language is at a late stage of losing independent V-to-I movement (or generalized V2) (Petersen 2000, Thráinsson 2003, Wiklund et al. 2009), though its syntax is argued to still be distinct from that of the Mainland North Germanic languages (see e.g. Heycock et al. 2010, 2012 for a direct comparison of Faroese and Danish). The loss of V-to-I movement is often claimed to coincide with the loss of rich inflection in the verbal paradigm, explaining the difference between Icelandic (where the finite verb obligatorily moves to a high position) and MNG with respect to verb placement in subordinate clauses (e.g., Platzack \& Holmberg 1989, Holmberg \& Platzack 1995). Like Icelandic and unlike MNG, Faroese still has person and number agreement on verbs although the system is partly reduced with no person distinctions in the plural. It has been suggested that the amount of inflectional morphology in the system no longer is enough to motivate independent V-to-I movement (Vikner 1995:147, Bobaljik \& Thráinsson 1998).

In Mainland North Germanic the loss of V-to-I movement was completed around 300 years ago (Falk 1993:155f, Vikner 1995:151, Sundquist 2003). Embedded Verb > Adverb orders are still found in MNG as the result of so-called "embedded verb second" (EV2). Typically this is restricted to a subset of clauses where the complement is (or could be) assertive (e.g., Bentzen et al. 2007, Julien 2007 and Wiklund et al. 2009). The standard analysis is that MNG utilises V-to-C movement in embedded clauses where the finite verb precedes sentence-medial adverbs. The relative acceptability of embedded Verb > Adverb in Faroese, and 
the status of embedded V2, is argued to be subject to idiolectal, generational and stylistic differences (see e.g. Petersen 2000, Jonas 2003, Thráinsson 2003, Heycock et al. 2012).

\section{[2.3] Word order in embedded wh-questions}

Faroese embedded wh-questions normally have subject-verb word order, with the subject being either the wh-word or a separate pronoun or phrase (in nonsubject wh-questions) (Thráinsson et al. 2012: 238-9). This is shown in the subject wh-question in (3a) and the non-subject wh-question in (3b) (adapted from Thráinsson et al. 2012:238, example (36)).
a. Eg spurdi, hvør gav Jógvani bókina.
I asked who.NOM gave Jógvan.DAT book.DEF 'I asked who gave the book to Jógvan.'
b. Eg spurdi, hvørjum Turið gav bókina. she asked who.DAT Turið.NOM gave book.DEF 'I asked who Turið gave the book to.'

Thráinsson et al. (2012:196, 303f) note that the relative marker ið 'that' may optionally follow the wh-constituent in both types of embedded wh-questions. This is in contrast to the MNG-pattern, where the complementizer som (No./Sw.) or $\operatorname{der}(\mathrm{Da}$.), otherwise found in relative clauses, is obligatory in subject wh-questions but disallowed in non-subject wh-questions.

\section{[3] THIS STUDY}

In order to study word order in embedded sentences in Faroese, an elicited production experiment was set up. Within the larger Nordic Word order Database project, the same experiment was run in Denmark, Norway and Sweden as well to further explore the status of embedded verb movement in North Germanic. ${ }^{2}$ The experiment covers two phenomena: the possibility of embedded V2 (i.e., Verb>Adverb order) in different clause types, and word order in embedded whquestions.

For the first phenomenon, the experiment tests the relative ordering of the finite verb and sentence adverbs in three different embedded contexts: bridgeverb complements, non-bridge predicate complements and indirect questions. Bridge-verb complements are assertive and we can therefore expect the Verb >

[2] The Nordic Word order Database is a collaboration between researchers from the University of Oslo and UiT The Arctic University of Norway. The experimental paradigm discussed in this paper (focussing on verb placement) was developed by Björn Lundquist and Maud Westendorp. The materials were checked by various native speakers, and several other researchers and research assistents helped with the data collection and analysis (see Acknowledgements). 
Adverb order to be produced in these contexts, at least in the MNG languages. However, Wiklund et al. (2009:1920) have proposed that true factives (i.e. our non-bridge predicates) disallow EV2 in MNG, as well as in Icelandic and Faroese, although not in subject-initial embedded clauses. Following Vikner (1995), embedded Verb > Adverb order should be available in embedded questions in Icelandic, but not in MNG. If V-to-I movement is still available for Faroese speakers, they might allow Verb > Adverb order in this context as well. Otherwise, we may expect Faroese to pattern with MNG in these clauses.

For the latter phenomenon, i.e., embedded wh-questions, we do not include any adverbs and test only the relative ordering of subject and verb and the use of a relative complementizer. We expect limited variation in Faroese, with the exception of optional insertion of the complementizer $i$.

\section{[3.1] Methodology}

All items are built up in the following way: the participant is presented with a subject-initial main clause (the so-called background sentence, (4a)), and is asked to read this sentence aloud. The background sentence is always preceded by a name in parentheses (in a different coloured font). The reading of the background sentence is followed by the appearance of a trigger (4b): the start of a new sentence, which the participant is asked to complete using the words from the background sentence. The clause in parentheses in (4b) is the target sentence the participant produces, with curly brackets showing the placement options of the embedded finite verb with respect to the adverb.
a. (Páll:) Eg
koyri ofta
bil til arbeiðis.
[background]
I drive often
'I often drive to work.'
b. Páll segði at...
Páll said that ...
(hann \{koyrir\} ofta \{koyrir\} bil til arbeiðis.)
he drives often drives car to work
car to work
'Páll says that he often drives to work.'

This transformation of main-to-embedded sentences allows us to test the placement of verbs with respect to adverbs, complementizers and other arguments in embedded clauses. ${ }^{3}$

[3] In the overview article (Lundquist et al. 2019), we describe the verb placement experiment as involving two different tasks/transformations: main-to-embedded and embedded-to-main clauses. The original aim of the experiment was to test embedded sentence word order in Faroese, and it was only later expanded to include the second task in subsequent fieldwork in the other North Germanic languages. (Other articles in this issue will detail this further.) 


\section{[3.2] Design and material}

The test items for this experiment were translated from Norwegian/Swedish by two native speakers of Faroese and piloted with a native speaker prior to the start of the fieldwork.

To target the placement of finite verbs in different types of embedded clauses, we used three different clause types: bridge-verb/assertive complements (segði at 'said that'), non-bridge/factive adjective complements (stoltur av at 'proud of'), indirect yes/no questions (spurdi um 'asked whether'). These clause types (BridgeV, Non-BridgeV, EmbQ) can be found in the drop-down menu "ExactCategory" when searching the Nordic Word order Database. Select "Verb - Adverb" in the Pairs-menu to view all items targeting embedded verb placement.

For these embedded Verb > Adverb items, we included two further sub-conditions: reflexivity of the verb and type of adverb. That is, for each clause type, we included 2 types of embedded verbs: non-reflexive (e.g., koyri 'drive') or reflexive verbs (e.g., raka scer 'shave oneself'). And 3 different medial adverbs (ofta 'often', aldri/ongantíð 'never', altíð 'always'). Note that we used two different versions of the adverbs meaning 'never'. This resulted in 6 different sentences $(2 \times$ 3 ) for each clause type. To select for these specific items, the drop-down menus "TypeElement1" (reflexivity) and "TypeElement 2" (adverb) in the database can be used to subset the results.

We used both non-reflexive and reflexive verbs to explore the possible interactions of verb movement and Object Shift. Given the well-known observation that Object Shift in North Germanic is conditioned by verb movement (Holmberg's Generalization, Holmberg 1986), we are interested in seeing if the presence of a light pronominal object (meg/seg 'my-/him-/herself') affects the probability of verb movement over the adverb.

The embedded Verb > Adv items were always followed by an embedded whquestion (main verb: spurdi 'asked' or vildi vita 'wanted to know'), where the whphrase was either the object or subject of the sentence, or by a declarative filler (main verb: er vís i at 'is sure that', heldur at 'states that'). Together these items act as fillers for the embedded Verb $>$ Adv condition. None of the fillers included adverbs or reflexive verbs. Examples of the two wh-question sub-conditions are given in (5) and (6). To view these categories in NWD, one can select the labels "EmbObQ" or "EmbSubQ" in the ExactCategory-menu.
a. (Katrin:) Hvagar fer Ása í feriu? where go Ása in spare.time
'Where is Ása spending her free time?'

b. Katrin spurdi ...

[background]

[trigger] 
Katrin asked

(hvagar \{fer\} Ása \{fer\} í feriu.)

[target]

where go Ása go in spare.time

'Katrin asked where Ása spends her free time.'

(6)

$\begin{array}{cllll}\text { a. (Ása:) Hvør } & \text { vann } & \text { kappingina } & \text { ígjár? } \\ \text { who } & \text { won } & \text { competition.DEF } & \text { yesterday } & \end{array}$

'Who won the competition yesterday?'

b. Ása vildi vita...

Ása wanted know.INF

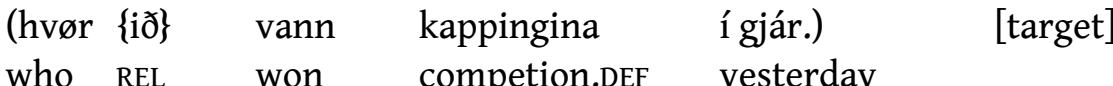

'Ása asked who won the competion yesterday.'

Table 1 below gives an overview of the material used in the experiment, and the number of items in each condition. The experiment consisted of two parts with 36 items in each part and a break in between. The test items from the first half of the test were repeated in the latter half changing only the proper names used in the sentences. The total number of items is $72(2 \times 36)$.

\begin{tabular}{ccc}
\hline Phenomenon/Condition & $\begin{array}{c}\text { Sub-condition: } \\
\text { clause type }\end{array}$ & $\begin{array}{c}\text { Total number } \\
\text { of items }\end{array}$ \\
\hline Embedded Verb > Adv & $\begin{array}{c}\text { bridge verb }(\mathrm{N}=6) \\
\text { non-bridge }(\mathrm{N}=6) \\
\text { indirect question }(\mathrm{N}=6)\end{array}$ & 18 \\
\hline Embedded wh-questions & $\begin{array}{c}\text { embedded subject question } \\
\text { embedded object question }\end{array}$ & 6 \\
\hline Declarative filler & & 6 \\
\hline Total & & 36 \\
\hline
\end{tabular}

TABLE 1: Overview of conditions and sub-conditions in the experiment.

\section{[3.3] Analysis}

All elicited responses were coded for word order/structure. The annotation can be accessed through the ProducedWordOrder menu in the database. For this specific experiment, the following codes are used: AV (Adverb > Verb) and VA (Verb $>$ Adverb) for the embedded verb placement items; SOM (complementizer present) and NON (no complementizer) for embedded subject wh-questions; VS (Verb > Subject) and SV (Subject > Verb) for object wh-questions; FILL for fillers 
and OTHER for all non-target-like responses.

I used $R$ (R Core Team 2019) and lme4 (Bates et al. 2012) to perform mixed effect logistic regression analyses. I chose this particular analysis because our response variables are categorical (utterances marked 'other' are disregarded in the analyses), our observations are dependent, and these models allow for both fixed and random effects.

\section{[3.4] Changes in the test items}

After the first day of testing (6/33 participants), we changed the main verb in the indirect question sub-condition. Originally, instead of spurdi um 'asked whether', these items had the main verb undrast um 'wonder about/be surprised/astonished at'. We meant to use the Faroese equivalent of 'wonder if/whether' to test verb placement in wh-complements but the Faroese verb undrast does however not usually take a wh-complement. Our use of this verb, as well as the preposition used in combination with it, brought up a lot of discussion during the first day of testing. Therefore, we decided to change to the verb spurdi um 'asked whether' in the indirect question condition for the remainder of the fieldwork. A note about how this affected the results will be made in Section 6 .

\section{[4] EXPERIMENTAL PROCEDURE}

Data collection took place in Tórshavn (August 23, 2018), Fuglafjørður (August 24,2018 ) and Klaksvík (August 26, 2018). Arrangements were made with contacts or teachers in the different locations in advance so that people were recruited to participate, and so that we were given access to rooms for conducting the experiment. The experiment was always carried out individually, in a separate room. A number of different researchers and research assistents conducted the experiments. The large team allowed us to test three or more participants at the same time. Instructions were provided mostly in Norwegian or Swedish, and sometimes in Faroese. If anything remained unclear, English was used to make sure that the participants understood the task.

The experiment was run on laptops using the software OpenSesame (Mathôt et al. 2012). We used handheld digital audio recorders (Zoom H2n/H4/H4nPro Handy Recorder) to record the sessions. A limited number of recordings were made with external lapel microphones (Audio-Technica ATR3350/AT8532), but most of them were done using the recorder microphone(s). The recordings were made in WAV-format at $44.1 \mathrm{kHz}$ audio sampling rate, with a bit depth of 16 .

\section{[5] PARTICIPANTS}

The Faroese data on embedded word order in the Nordic Word order Database 
includes utterances from 33 unique participants. Of these, 15 were younger than 20 years old at the time of recording, and these participants all attended a high school in Fuglafjørður. We recruited older participants by putting out a call on Facebook. All participants were volunteers. The high school students received a small gift as a thank you for their time. All participants were native speakers of Faroese; three participants had additional, simultaneously acquired, first languages (English/Danish). An overview of the participants in the experiment is given in Table 2.

\begin{tabular}{cccc}
\hline Location & $\begin{array}{c}\text { Number of } \\
\text { participants }\end{array}$ & $\begin{array}{c}\text { Gender } \\
\text { (male/female) }\end{array}$ & $\begin{array}{c}\text { Age range } \\
\text { (mean) }\end{array}$ \\
\hline Tórshavn & 6 & $(2 / 4)$ & $47-69(55)$ \\
Fuglafjørður & 15 & $(4 / 11)$ & $17-19(18.5)$ \\
Klaksvík & 12 & $(3 / 9)$ & $23-65(46.4)$ \\
\hline Total & $\mathbf{3 3}$ & $\mathbf{( 9 / 2 4 )}$ & $\mathbf{1 7 - 6 9 ( 3 5 . 3 )}$ \\
\hline
\end{tabular}

TABLE 2: Overview of Faroese participants.

[6] OVERVIEW RESULTS

\section{[6.1] Embedded verb placement}

We tested three types of embedded contexts to examine the possibility of embedded Verb > Adverb in Faroese: complement of a bridge verb, complement of non-bridge verb, and embedded yes/no questions.

The participants made two common mistakes that made it impossible to code some of the data for the order of embedded verb and adverb $(2.61 \%$ of the relevant items): the adverb was missing or the infinitive was used in the factive/nonbridge subcondition (exemplified by an elicited response from the database in (7a), cf. the target (7b)).

(7) a. Ása er stolt av at altíð at súkkla til arbeiðis. [FAR032] Asa is proud of COMP always INF bike.INF to work

'Asa is proud of always biking to work.'

b. Ása er stolt av at hon altíð súkklar til arbeiðis. [target] Asa is proud of comp she always bikes to work

'Asa is proud that she always bikes to work.'

The results for the embedded verb placement condition, split over the different clause types, are presented in Table 3. We observe that Verb>Adverb order is significantly more common after a verb that selects for an assertive complement 
than a non-assertive complement or an embedded question $(\mathrm{p}<0.001) .{ }^{4}$ Excluding the embedded questions where undrast was used as the main verb (see discussion in Section 3.4), does not notably change the proportion of $\mathrm{V}>\mathrm{A}$ used (see two rightmost columns). This difference in proportion of Verb>Adverb orders between bridge verb complements (40\%) and embedded questions (7\%) indicates that (at least some) Faroese speakers have reanalysed this word order as V-to-C movement.

\begin{tabular}{ccccc}
\hline $\begin{array}{c}\text { Produced } \\
\text { word order }\end{array}$ & $\begin{array}{c}\text { bridge verb } \\
\text { complement (\%) }\end{array}$ & $\begin{array}{c}\text { factive adjective } \\
\text { complement (\%) }\end{array}$ & $\begin{array}{c}\text { indirect } \\
\text { question (\%) }\end{array}$ & $\begin{array}{c}\text { excl. un- } \\
\text { drast (\%) }\end{array}$ \\
\hline $\begin{array}{c}\text { Adverb > Verb } \\
\text { Verb > Adverb }\end{array}$ & $235(59.3)$ & $312(78.8)$ & $362(91.4)$ & $298(92.0)$ \\
Other & $161(40.7)$ & $59(14.9)$ & $28(7.1)$ & $23(7.1)$ \\
0 & $25(6.3)$ & $6(1.5)$ & $3(0.9)$ \\
\hline $\begin{array}{c}\text { Total } \\
\text { observations }\end{array}$ & $\mathbf{3 9 6 ( 1 0 0 )}$ & $\mathbf{3 9 6 ( 1 0 0 )}$ & $\mathbf{3 9 6 ( 1 0 0 )}$ & $\mathbf{3 2 4 ( 1 0 0 )}$ \\
\hline
\end{tabular}

TABLE 3: Overview embedded word orders accross clause types.

Half of the embedded Verb > Adverb items contained a reflexive verb, which provided information about possible interaction between verb movement and object shift. We observe an increase in the likelihood of verb movement over the adverb when a light object reflexive is present. See Table 4 for an overview across all clause types. In the bridge verb complements, where Verb > Adverb order is most common, the mixed effects logistic regression model showed that reflexivity affected word order choice $\left(\chi^{2}(1)=4.4157, \mathrm{p}<0.05\right)$, increasing the odds of Verb > Adverb order by $0.8414(\mathrm{p}<0.05) .{ }^{5}$ This increase in the likelihood of verb movement when a light object reflexive is present seems to indicate that Object Shift feeds verb movement, although only in a highly probabilistic fashion.

[4] This analysis includes the items using undrast as the main verb in the indirect question sub-condition. Random effects: Item, Participant, Adverb

\begin{tabular}{|c|c|c|c|c|}
\hline & Estimate & Std. Er & z-value & $\operatorname{Pr}(>|z|)$ \\
\hline (Intercept) & 0.6444 & 0.4731 & 1.362 & 0.173 \\
\hline Non-Bridge complements & 2.4627 & 0.3223 & 7.641 & $2.15 \mathrm{e}-14^{* * *}$ \\
\hline Indirect questions & 3.7346 & 0.3833 & 9.743 & $<2 \mathrm{e}-16$ *** \\
\hline
\end{tabular}

[5] Reflexivity was used as a fixed effect; as random effects we had intercepts for participants and items, as well as type of adverb. $\mathrm{b} 0=-1.0512, \mathrm{~b}=0.8414, \mathrm{SE}=0.3413$ and $\mathrm{p}=0.0137$ *; model $\mathrm{C}=0.9493723$ 


\begin{tabular}{ccccc}
\hline & Adverb > Verb (\%) & Verb > Adverb (\%) & Other (\%) & Total \\
\hline $\begin{array}{c}\text { non-reflexive } \\
\text { reflexive }\end{array}$ & $481(81.0)$ & $100(16.8)$ & $13(2.2)$ & $\mathbf{5 9 4 ( 1 0 0 )}$ \\
\hline Total & $428(72.1)$ & $148(24.9)$ & $18(3.0)$ & $\mathbf{5 9 4 ( 1 0 0 )}$ \\
\hline
\end{tabular}

TABLE 4: Interaction of reflexivity and word order.

Three different adverbs were used in the embedded V2 condition: never, always and often (see Section 3.2 for a note on the Faroese translations of these adverbs). Table 5 shows the distribution of the produced word orders across the different adverbs.

\begin{tabular}{cccc}
\hline $\begin{array}{c}\text { Produced } \\
\text { word order }\end{array}$ & never (\%) & always (\%) & often (\%) \\
\hline Adverb > Verb & $318(80.3)$ & $304(76.7)$ & $287(72.5)$ \\
Verb > Adverb & $70(17.7)$ & $85(21.5)$ & $93(23.9)$ \\
Other & $8(2.0)$ & $7(1.7)$ & $16(4.0)$ \\
\hline Total & $\mathbf{3 9 6 ( 1 0 0 )}$ & $\mathbf{3 9 6 ( 1 0 0 )}$ & $\mathbf{3 9 6 ( 1 0 0 )}$ \\
\hline
\end{tabular}

TABLE 5: Overview embedded word orders with different adverbs.

A mixed effects model of the relationship between the produced word order and the different adverbs was fitted. The type of adverb significantly affected the choice of word order $\left(\chi^{2}(2)=9.2668, p<0.01\right)$. There is a small but significant difference in the probability of Verb $>$ Adverb order occurring with the 'low' adverb often (odds: $0.8585, \mathrm{p}<0.01$ ) but not for the other two adverbs. ${ }^{6}$ This finding is in line with earlier findings in an acceptability judgement task by Bentzen et al. (2009), who report that verb movement across adverbs like ofta 'often' is accepted by many Faroese speakers. This stands in contrast to verb movement in embedded questions and relative clauses across adverbs such as ongantíð 'never', which is often rejected.

\section{[6.2] Embedded wh-questions}

We find almost no variation in the word order used in the embedded wh-questions. These wh-questions never included adverbs and are almost exclusively produced with Subject > Verb order as expected. Deviations from this pattern

[6] As fixed effects, I used the type of adverb; intercepts for participants and items, as well as clause type and reflexivity were added as random intercepts. $\mathrm{b} 0=-3.1878, \mathrm{~b}=0.8585, \mathrm{SE}=0.2805$ and $\mathrm{p}=0.00220 * *$; model $\mathrm{C}=0.9396115$ 
(i.e., $\mathrm{V}>\mathrm{S}$ order) are found in 3 embedded object questions in the database (produced by 3 different speakers), and 3 of the embedded subject questions include the relative complementizer ið (see (8); produced by 2 speakers).

(8)

$\begin{array}{lllll}\text { Páll } & \text { vildi } & \text { vita } & \text {... } & \\ \text { Páll } & \text { wanted } & \text { know.INF } & & \\ \text { hvør } & \text { ið } & \text { var } & \text { í ballinum í gjárkvøldið. } \\ \text { who } & \text { REL } & \text { was } & \text { in party.DEF yesterday.night.DEF } \\ \text { 'Páll wanted to know who was at the party yesterday.' }\end{array}$

[7] DisCUSSION AND REMAINING QUESTIONS

The results from the Faroese fieldwork to a large extent confirm previous research. As expected, we find very little variation in word order of embeddded wh-questions. For embedded verb movement, we observe similar rates of Verb > Adverb order in declarative complements as Heycock et al. (2012) report in their language samples. That is, we find $40.7 \% \mathrm{~V}>\mathrm{A}$ order in our bridge verb context; Heycock et al. found Verb $>$ Negation order in $39 \%$ of embedded that-sentences in speech and 45\% in written texts (2012:572). The overall Faroese rates of $\mathrm{V}>\mathrm{A}$ are much higher than those found in the Nordic Word order Database for the Mainland North Germanic languages where Verb > Adverb order is much more rare, even in assertive embedded clauses. In contrast to bridge verb complements, Faroese non-bridge complements and embedded questions disfavour the $\mathrm{V}>\mathrm{A}$ order. In these contexts, Faroese seems to pattern more with the MNG languages than with Icelandic.

It should be noted that our experiment only included subject-initial embedded contexts. In these contexts, V-to-I and V-to-C movement provide two potentially different sources for Verb>Adverb order. The effects of V-to-I and embedded V2 can therefore not easily be distinguished. However, the fact that we find a sensitivity to clause type indicates that it is mainly V-to-C, not V-to-I we see here. Further research, looking for example at island-effects in these contexts, could provide additional evidence to distinguish the effects of the two types of movement (see e.g. Heycock et al. 2012 for an acceptability judgement study designed to do exactly this).

\section{AC KNOWLEDGMENTS}

This research is supported the RCN project 'Variation and Change in the Scandinavian Verb Phrase' (project number: 250755, PI: Ida Larsson). The RCN grant covered expenses associated with project development, fieldwork and annotation of the collected material. Westendorp's contribution is funded through her PhD project at CASTL, UiT The Arctic University of Norway. 
This work would also not have been possible without the generous help of Solveig Malmsten and Annika Simonsen who spent considerable time translating the experimental items; Rakul Absalonsen and Gunnvør Brimnes who helped us recruit and test participants; Filippa Lindahl who joined us for the fieldwork; Anna Katharina Pilsbacher who helped annotate the data; Fróðskaparsetur Føroya, Miðnám á Kambsdali and Íverksetarahúsið who hosted us for this fieldwork; and all the Faroese participants who gave of their time to work with us. Lastly, I would like to thank the NALS reviewers and editors for their helpful comments.

\section{REFERENCES}

Bates, Douglas, Martin Maechler, Ben Bolker, and Steve Walker. 2015. Fitting Linear Mixed-Effects Models Using lme4. Journal of Statistical Software 67(1). 1-48. https://doi.org/10.18637/jss.v067.i01

Bentzen, Kristine, Gunnar Hrafn Hrafnbjargarson, Porbjörg Hróarsdóttir, and Anna-Lena Wiklund. 2007. The Tromsø Guide to the Force Behind V2. Working Papers in Scandinavian Syntax 79. 93-118.

Bentzen, Kristine, Piotr Garbacz, Caroline Heycock, and Gunnar Hrafn Hrafnbjargarson. On variation in Faroese verb placement. Nordlyd 36(2). 78-102.

Bobaljik, Jonathan David and Höskuldur Thráinsson. 1998. Two Heads Aren't Always Better than one. Syntax 1(1). 37-71. https://doi.org/10.1111/14679612.00003

Falk, Cecilia. 1993. Non-referential subjects and agreement in the history of Swedish. Lingua 89(2-3). 143-180. https://doi.org/10.1016/0024-3841(93)90051W

Føroya landsstýri. 2019. FaroeIslands.fo: The Official Gateway to the Faroe Islands. Accessed April 2020. https://www.faroeislands.fo/arts-culture/language/

Heycock, Caroline, Antonella Sorace, and Zakaris Svabo Hansen. 2010. V-to-I and V2 in Subordinate Clauses: An Investigation of Faroese in Relation to Icelandic and Danish. Journal of Comparative Germanic Linguistics 13. 61-97. https://doi.org/10.1007/s10828-010-9035-7

Heycock, Caroline, Antonella Sorace, Zakaris Svabo Hansen, Frances Wilson, and Sten Vikner. 2012. Detecting the Late Stages of Syntactic Change: The Loss of V-to- $\mathrm{T}$ in Faroese. Language 88(3). 558-600. https://doi.org/10.1353/lan.2012.0053 
Holmberg, Anders. 1986. Word order and syntactic features in the Scandinavian languages and English. Doctoral Dissertation, Stockholm University.

Holmberg, Anders and Christer Platzack. 1995. The Role of Inflection in Scandinavian Syntax. Oxford University Press.

Jonas, Dianne. 2003. On embedded clause word order in Faroese. In Lars-Olof Delsing, Cecilia Falk, Gunlög Josefsson, and Halldór Á. Sigurðsson (eds.), Grammatik i fokus. Festskrift till Christer Platzack, vol. II, 193-198. Lund: Department of Scandinavian Linguistics, Lund University.

Julien, Marit. 2007. Embedded V2 in Norwegian and Swedish. Working Papers in Scandinavian Syntax 80. 103-161. https://lup.lub.lu.se/record/1032083

Lundquist, Björn, Ida Larsson, Maud Westendorp, Eirik Tengesdal, and Anders Nøklestad. 2019. Nordic Word Order Database: Motivations, Methods, Material and Infrastructure. Nordic Atlas of Language Structures (NALS) Journal 4(1). 1-33. https://doi.org/10.5617/nals.7529

Lundquist, Björn. 2020. Argument placement in Faroese. Nordic Atlas of Language Structures (NALS) Journal 5(1). 5-27.

Nordic Word order Database [Dataset]. University of Oslo: the Text Laboratory. https://tekstlab.uio.no/nwd

Mathôt, Sebastiaan, Daniel Schreij, and Jan Theeuwes. 2012. OpenSesame: An Open-Source, Graphical Experiment Builder for the Social Sciences. Behavior Research Methods 44(2). 314-324. https://doi.org/10.3758/s13428-011-0168-7

Petersen, Hjalmar P. 2000. IP or TP in modern Faroese. Working Papers in Scandinavian Syntax 66. 75-83.

Petersen, Hjalmar P. 2010. The Dynamics of Faroese-Danish Language Contact. Universitätsverlag Winter.

Platzack, Christer and Anders Holmberg. 1989. The Role of AGR and Finiteness in Germanic VO languages. Working Papers in Scandinavian Syntax 43. 51-76.

R Core Team. 2019. R: A Language and Environment for Statistical Computing. R Foundation for Statistical Computing. https://www.R-project.org/

Sundquist, John D. 2003. The Rich Agreement Hypothesis and Early Modern Danish Embedded-Clause Word Order. Nordic Journal of Linguistics 26(2). 233-258. https://doi.org/10.1017/S0332586503001094 
Thráinsson, Höskuldur. 2003. Syntactic Variation, Historical Development, and Minimalism. In Randall Hendrick (ed.), Minimalist syntax, chap. 4, 152-191. Blackwell. https://doi.org/10.1002/9780470758342.ch4

Thráinsson, Höskuldur, Hjalmar P. Petersen, Jógvan í Lon Jacobsen, and Zakaris Svabo Hansen. 2012. Faroese: An Overview and Reference Grammar. $2^{\text {nd }}$ ed. Føroya Fróðskaparfelag.

Vikner, Sten. 1995. Verb Movement and Expletive Subjects in the Germanic Languages. Oxford University Press.

Wiklund, Anna-Lena, Kristine Bentzen, Gunnar Hrafn Hrafnbjargarson, and porbjörg Hróarsdóttir. 2009. On the Distribution and Illocution of V2 in Scandinavian That-Clauses. Lingua 119(12). 1914-1938. https://doi.org/10.1016/j.lingua.2009.03.006

CONTACT

Maud Westendorp

Centre for Advanced Study in Theoretical Linguistics (CASTL)

UiT The Arctic University of Norway

maud. westendorp@uit.no 